\title{
The Politics \\ of Duplicity
}

Controlling Reproduction in Ceausescu's Romania

\section{Gail Kligman}


University of California Press

Berkeley and Los Angeles, California

University of California Press, Ltd.

London, England

(C) 1998 by

The Regents of the University of California

Library of Congress Cataloging-in-Publication Data

Kligman, Gail.

The politics of duplicity: controlling reproduction in

Ceausescu's Romania / Gail Kligman.

p. $\mathrm{cm}$.

Includes bibliographical references (p. ) and index.

ISBN 0-520-2 1074-3 (alk. paper). - ISBN o-520-2 1075-1 (pbk.: alk. paper)

1. Romania-Population policy. 2. Birth control-Moral and ethical aspects-Romania. 3. Romania-Politics and government-1944-1989. 4. Romania-Social conditions. I. Title. $\mathrm{HB}_{3} 63_{3} \cdot \mathrm{K}_{5} 8 \quad 1998$

$363.9^{\circ} 09498-\mathrm{dc} 21$

$97-494^{2} 1$

CIP

Printed in the United States of America

$\begin{array}{lllllllll}9 & 8 & 7 & 6 & 5 & 4 & 3 & 2 & 1\end{array}$

The paper used in this publication meets the minimum requirements of American National Standards for Information Sciences-Permanence of Paper for Printed Library Materials, ANSI Z39-48-1984. 
For my mother, Dr. Beatrice Troyan, obstetrician-gynecologist 
